\title{
2
}

\section{Detection of Group 1 Coronaviruses in Bats Using Universal Coronavirus Reverse Transcription Polymerase Chain Reactions}

\author{
Leo L. M. Poon and J. S. Malik Peiris
}

\begin{abstract}
The zoonotic transmission of SARS coronavirus from animals to humans revealed the potential impact of coronaviruses on mankind. This incident also triggered several surveillance programs to hunt for novel coronaviruses in human and wildlife populations. Using classical RT-PCR assays that target a highly conserved sequence among coronaviruses, we identified the first coronaviruses in bats. These assays and the cloning and sequencing of the PCR products are described in this chapter. Using the same approach in our subsequent studies, we further detected several novel coronaviruses in bats. These findings highlighted the fact that bats are important reservoirs for coronaviruses.
\end{abstract}

Key words: bat coronaviruses; novel coronaviruses; molecular detection; RT-PCR

\section{Introduction}

Coronaviruses are a group of enveloped, positive-strand single stranded RNA viruses with a corona-like morphology. These viruses have genome sizes ranging from 28 to $32 \mathrm{~kb}$, which makes them the biggest among the RNA viruses (1). The genomes contain five major open reading frames (Orfs) that encode the replicase polyproteins (Orf 1a and Orf 1ab), spike (S), envelope (E), membrane $(\mathrm{M})$, and nucleocapsid $(\mathrm{N})$ proteins, in that order. Based on antigenic and genetic analyses, coronaviruses can be subdivided into three groups. Coronaviruses from groups 1 and 2 have been found to infect mammals. By contrast, avian species are known to be the natural hosts for group 3 viruses. Most coronaviruses

From: Methods in Molecular Biology, vol. 454: SARS- and Other Coronaviruses,

Edited by: D. Cavanagh, DOI: 10.1007/978-1-59745-181-9_2, C Humana Press, New York, NY 
are pathogenic to their hosts $(2,3)$. Animal coronaviruses are known to cause respiratory, gastrointestinal, neurological, and hepatic diseases. By contrast, with the exception of SARS coronavirus, in the case of healthy individuals all previously known human coronaviruses were generally only associated with mild respiratory and gastrointestinal diseases.

The discovery of a novel coronavirus as the cause of SARS led to a resurgence in interest in these viruses and to the discovery of other novel coronaviruses in humans, namely NL-63 and HKU-1 (4-6). The recognition of SARS-like coronaviruses in palm civets and other small mammals in live-game animal markets (7) prompted intensive surveillance for coronaviruses in wild animals. Following upon this interesting discovery, several novel coronaviruses were identified in the mammalian and avian species $(\mathbf{6}, \mathbf{8 - 1 7 )}$. In particular, our initial studies first revealed that bats are important reservoirs for coronaviruses. By screening respiratory and fecal samples collected from a wide range of animals, we identified the first coronavirus in bats (14). Subsequent studies by ourselves and others also indicated that there are number of group 1 and group 2 viruses circulating in bat species $(11,12,15,17)$. In particular, a SARS-like coronavirus was found in two of these studies independently $(11,12)$. These results suggest that bats might play a key role in the evolution of coronaviruses. Here we describe the procedures that were used in our virus surveillance studies.

\section{Materials}

\subsection{Sampling}

1. Viral transport medium: Dissolve $12.5 \mathrm{~g}$ of penicillin $\mathrm{G}$ sodium salt (SigmaAldrich), $50 \mathrm{mg}$ of ofloxacin (Sigma-Aldrich), $0.1 \mathrm{~g}$ of nystatin (Sigma-Aldrich), 12.5 million units of polymycin B sulfate salt (Sigma-Aldrich), $250 \mathrm{mg}$ gentamicin (Sigma-Aldrich), $1 \mathrm{~g}$ of sulfamethoxazole (Sigma-Aldrich), $0.2 \mathrm{~g}$ of sodium hydroxide (Merck), and $2.2 \mathrm{~g}$ of sodium hydrogen carbonate (Merck) in 1 liter of Medium 199 (Sigma-Aldrich). Adjust to $\mathrm{pH}$ 7.0-7.5 with sodium hydrogen carbonate solution and filter the solution using a $0.22-\mu \mathrm{m}$ pore size filter. Store the filtered medium in aliquots in sterile screw cap tubes $(1 \mathrm{ml} /$ tube) (Axygen Scientific) at $-20^{\circ} \mathrm{C}$ (see Note 1).

2. Calcium alginate swabs with an ultrafine aluminum shaft (Fisher Scientific).

3. Portable ice bucket with reusable cooling packs.

4. Cotton work gloves.

5. Sampling net.

\subsection{RNA Extraction}

1. QIAamp virus RNA mini kit (Qiagen) (see Note 2).

2. Ethanol, $96-100 \%$.

3. Autoclaved RNase-free water or its equivalent. 


\subsection{Reverse Transcription}

1. SuperScript III reverse transcriptase, $200 \mathrm{U} / \mu \mathrm{L}$ (Invitrogen).

2. $5 \mathrm{X}$ first-strand buffer: $250 \mathrm{mM}$ Tris- $\mathrm{HCl}(\mathrm{pH} 8.3), 375 \mathrm{mM} \mathrm{KCl}, 15 \mathrm{mM} \mathrm{MgCl} 2$ (Invitrogen).

3. $0.1 \mathrm{mM}$ dithiothreitol (Invitrogen).

4. Random hexamers, $3 \mu \mathrm{g} / \mu \mathrm{l}$ (Invitrogen).

5. RNaseOUT recombinant ribonuclease inhibitor, $40 \mathrm{U} / \mu \mathrm{l}$ (Invitrogen).

6. Deoxynucleotide triphosphates (dNTP).

7. Autoclaved RNase-free water or equivalent.

8. Heating block or equivalent.

\subsection{Polymerase Chain Reaction}

1. AmpliTaq Gold DNA polymerase, $5 \mathrm{U} / \mu \mathrm{l}$ (Applied Biosystems).

2. 10X Gold PCR buffer (Applied Biosystems).

3. Deoxynucleotide triphosphates (dNTP).

4. $25 \mathrm{mM} \mathrm{MgCl}_{2}$ solution (Applied Biosystems)

5. $10 \mu \mathrm{M}$ PCR forward primer, 5'-GGTTGGGACTATCCTAAGTGTGA-3'

6. $10 \mu \mathrm{M}$ PCR reverse primer, 5' - CCATCATCAGATAGAATCATCAT-3'

7. Themocycler (GeneAmp 9700, Applied Biosystems)

\subsection{Gel Electrophoresis}

1. 50X TAE buffer (Bio Rad).

2. Seakam LE agarose powder (Cambrex).

3. $6 \mathrm{X}$ gel loading buffer: $10 \mathrm{mM}$ Tris- $\mathrm{HCl}$ ( $\mathrm{pH} 7.6), 0.03 \%$ bromophenol blue, $0.03 \%$ xylene cyanol, $60 \%$ glycerol, and $60 \mathrm{mM}$ EDTA.

4. $1 \mathrm{~kb}$ plus DNA ladder markers (Invitrogen).

5. Ethidium bromide, $10 \mathrm{mg} / \mathrm{ml}$ (see Note 3).

6. Agarose gel electrophoresis apparatus.

7. Power supply (PowerPac Basic, Bio-Rad).

8. Gel documentary machine or equivalent.

\subsection{PCR Products Purification}

1. QIAquick PCR purification kit (Qiagen).

2. Ethanol, 96-100\%.

\subsection{PCR Product Cloning}

1. TOPO TA cloning kit with electrocompetent E. coli (Invitrogen).

2. Electroporation system (Gene Pulser Xcell, Bio-Rad). 
3. Electroporation cuvettes (Gap width: $0.2 \mathrm{~cm}$, Bio-Rad).

4. LB plate containing $50 \mu \mathrm{g} / \mathrm{ml}$ ampicillin.

\subsection{Sequencing}

1. BigDye Terminator v3.1 Cycle Sequencing kit (Applied Biosystems).

2. Spectrophotometer.

3. 3.2- $\mu \mathrm{M}$ sequencing primers (forward/reverse primers mentioned in Section 2.4)

4. Dye terminator removal columns (Genetix)

5. DNA analyzer (3700, Applied Biosystems) or equivalent.

\section{Methods}

The protocol described below was used to detect group 1 bat coronavirus in our previous studies (14). The procedures and primer set for the assay can also detect other non-group-1 coronaviruses in other specimens. In our studies, this assay was also shown to be able to detect other common human coronaviruses in our hands (e.g., HKU1, NL63, OC43, and 229E).

As the primer set used in our studies would cross-react with a wide range of coronaviruses (Fig. 1), all the positive products from the PCR reactions should first be identified by DNA sequencing. Moreover, amplicons from our

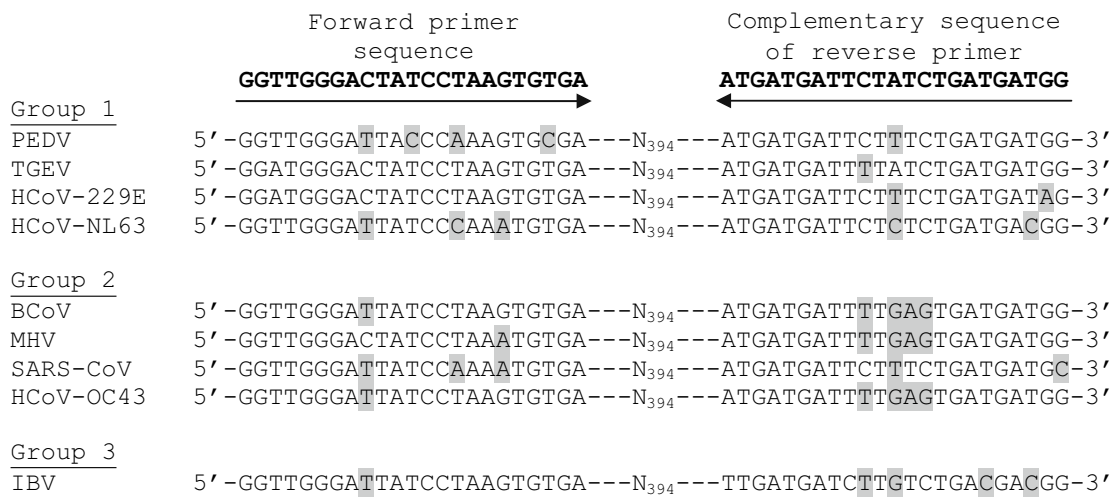

Fig. 1. Sequence alignment of the target regions of representative coronaviruses. Forward and reverse primers were communicated through the World Health Organization's SARS etiology network by colleagues from the Centers for Disease Control and Prevention. The forward primer and complementary sequence of the reverse primer correspond to the nucleotide positions 15149 to 15171 and 15567-15589 of HCoV-OC43 (Genbank accession no: AY585229), respectively. 
PCR assays were sometimes found to contain many single-nucleotide polymorphisms. To obtain more accurate sequencing data for our phylogenetic analysis, PCR products from these reactions were cloned into vectors (Section 3.8) and several clones from the same PCR reactions were chosen for sequencing analysis.

To enhance the detection rate of bat coronaviruses, we also developed a heminested PCR assay to detect group 1 bat corornaviruses identified from our earlier study (Section 3.6) (8). However, we did not evaluate the performance of this hemi-nested PCR assay to detect other coronaviruses.

\subsection{Sample Collection}

1. Trap the animal with a sampling net and handle it with appropriate protective equipment (e.g., cotton work gloves or leather gloves) (see Notes 4 and 5).

2. Examine the animal and record its physical parameters/features for species identification.

3. For collecting throat swab samples, insert swab into the animal's throat and leave it in place for a few seconds to absorb secretions. For collecting anal swab samples, insert swab into the anus and leave it in place for a few seconds (see Note 6).

4. Immediately place the swab into a sterile vial containing $1 \mathrm{ml}$ of viral transport medium. Label each specimen properly.

5. Put the specimen vials on ice for transport to the laboratory. Do not freeze.

6 . Vortex the specimen vial briefly in the laboratory. Transfer $500 \mu$ l of viral transport medium into a new sterile vial at $-70^{\circ} \mathrm{C}$ for long-term storage. If the remaining half of the sample cannot be processed for RNA extraction (or virus isolation) on the same day, store it at $4^{\circ} \mathrm{C}$ until use (see Note 7).

\subsection{RNA Extraction}

1. For a new kit, perform the following procedures before specimen processing:

a. Add $1 \mathrm{ml}$ of buffer AVL to a tube of lyophilized carrier RNA $(310 \mu \mathrm{g})$. Dissolve carrier RNA thoroughly. Transfer to the buffer AVL bottle and mix thoroughly. Store the buffer AVL at $4^{\circ} \mathrm{C}$ for up to 6 months.

b. For every $19 \mathrm{ml}$ of buffer AW1, add $25 \mathrm{ml}$ of ethanol (96-100\%). Mix well. Store the buffer AW1 at room temperature for up to 12 months.

c. For every $13 \mathrm{ml}$ of buffer AW2, add $30 \mathrm{ml}$ of ethanol (96-100\%). Mix well. Store the buffer AW1 at room temperature for up to 12 months (see Note 2).

2. Equilibrate all reagents to room temperature before use.

3. Pipette $140 \mu \mathrm{l}$ of the sample into a $1.5-\mathrm{ml}$ microcentrifuge tube.

4. Add $560 \mu$ l of prepared buffered AVL with carrier RNA to the microcentrifuge tube.

5. Briefly vortex the tubes for $15 \mathrm{sec}$ and incubate at room temperature for $10 \mathrm{~min}$. 
6. Briefly centrifuge the microcentrifuge tube. Add $560 \mu$ l ethanol (96-100\%) and mix by pulse vortexing for $15 \mathrm{sec}$.

7. Briefly centrifuge the microcentrifuge tube.

8. Transfer $630 \mu \mathrm{l}$ of the solution from the tube to a QIAamp spin column placed in a 2 -ml collection tube. Centrifuge at $6000 \times g(8000 \mathrm{rpm})$ for $1 \mathrm{~min}$. Place the spin column in a clean $2-\mathrm{ml}$ collection tube. Discard the tube containing the filtrate.

9. Open the spin column and repeat step 8.

10. Add $500 \mu \mathrm{l}$ buffer AW1. Centrifuge at $6000 \times g(8000 \mathrm{rpm})$ for $1 \mathrm{~min}$. Place the spin column in a clean $2-\mathrm{ml}$ collection tube. Discard the tube containing the filtrate.

11. Add $500 \mu \mathrm{l}$ buffer AW2. Centrifuge at $20,000 \times g(14,000 \mathrm{rpm})$ for $3 \mathrm{~min}$. Place the spin column in a clean 2-ml collection tube and centrifuge at 20,000 $\times g$ again for $1 \mathrm{~min}$. Place the spin column in a clean $1.5-\mathrm{ml}$ microcentrifuge tube. Discard the tube containing the filtrate.

12. Apply $60 \mu \mathrm{l}$ buffer AVE equilibrated to room temperature directly on the membrane of the column. Close the cap and incubate at room temperature for $1 \mathrm{~min}$.

13. Centrifuge at $6000 \times g(8000 \mathrm{rpm})$ for $1 \mathrm{~min}$. Collect the filtrate for cDNA synthesis. Store the RNA at $-20^{\circ} \mathrm{C}$ or $-70^{\circ} \mathrm{C}$ (see Note 8).

\subsection{Reverse Transcription}

1. Prepare a reverse transcription master mix sufficient for the designated number $(N)$ of samples in a sterile 1.5-ml microcentrifuge tube as shown in Table 1.

2. Vortex and centrifuge the tube briefly. Keep the tube on ice.

3. Add $10 \mu \mathrm{l}$ of master mix solution into separate 0.5 -microcentrifuge tubes. Label the tubes accordingly and keep them on ice.

4. Add $10 \mu \mathrm{l}$ of purified RNA sample into these tubes.

5. Vortex and centrifuge the tubes briefly.

\section{Table 1}

\section{Composition of the Reverse Transcription Reaction}

\begin{tabular}{lccl}
\hline Reagent & $\begin{array}{c}\text { Volume per } \\
\text { reaction }\end{array}$ & $\begin{array}{c}\text { Volume mix } \\
\text { for N reactions }\end{array}$ & $\begin{array}{c}\text { Final } \\
\text { concentration }\end{array}$ \\
\hline 5X First-strand buffer & $4 \mu \mathrm{l}$ & $4 \times \mathrm{N} \mu \mathrm{l}$ & $1 \times$ \\
$0.1 \mathrm{mM}$ DTT & $2 \mu \mathrm{l}$ & $2 \times \mathrm{N} \mu \mathrm{l}$ & $0.01 \mathrm{mM}$ \\
$10 \mathrm{mM}$ dNTP & $1 \mu \mathrm{l}$ & $\mathrm{N} \mu \mathrm{l}$ & $0.5 \mathrm{mM}$ \\
Random primers $(50 \mathrm{ng} / \mu \mathrm{l})$ & $1 \mu \mathrm{l}$ & $\mathrm{N} \mu \mathrm{l}$ & $2.5 \mathrm{ng} / \mu \mathrm{l}$ \\
Reverse transcriptase $(200 \mathrm{U} / \mu \mathrm{l})$ & $1 \mu \mathrm{l}$ & $\mathrm{N} \mu \mathrm{l}$ & $200 \mathrm{U} /$ reaction \\
Ribonuclease inhibitor & $1 \mu \mathrm{l}$ & $\mathrm{N} \mu \mathrm{l}$ & $40 \mathrm{U} /$ reaction \\
Total volume of master mix & $10 \mu \mathrm{l}$ & $10 \times \mathrm{N} \mu \mathrm{l}$ & - \\
\hline
\end{tabular}


6. Stand the tubes at room temperature for $10 \mathrm{~min}$ and then incubate at $42^{\circ} \mathrm{C}$ for $50 \mathrm{~min}$.

7. Inactivate the transcription reaction by incubating the tubes at $95^{\circ} \mathrm{C}$ for $5 \mathrm{~min}$ and then chill the samples on ice. Store the cDNA samples at $-20^{\circ} \mathrm{C}$ (see Note 9).

\subsection{PCR Assay}

1. Prepare a PCR master mix sufficient for the designated number of samples in a sterile $0.5-\mathrm{ml}$ microcentrifuge tube according to Table 2 . Include at least 1 positive control and 1 negative control (water) for each run. Add additional controls (e.g., purified RNA from the studied samples) as necessary.

2. Vortex and centrifuge the tube briefly. Keep the tube on ice.

3. Aliquot $48 \mu \mathrm{l}$ of the master mix into separate $0.5-\mathrm{ml}$ microcentrifuge tubes and label the tubes accordingly.

4. Add $2 \mu \mathrm{l}$ of cDNA generated from the reverse transcription reactions to the tubes. For the positive control, add $2 \mu \mathrm{l}$ of coronavirus cDNA into the reaction. For the negative control, add $2 \mu l$ of autoclaved water.

5. Vortex and centrifuge the tubes briefly.

6. Run the PCR under the conditions shown in Table 3.

7. After the run, analyze the PCR products by gel electrophoresis. Before gel electrophoresis, the PCR reactions can be kept at $-20^{\circ} \mathrm{C}$ for short-term storage.

\subsection{Agarose Gel Electrophoresis}

1. Place a gel-casting tray onto a gel-casting base. Level the base.

2. Prepare $1.5 \%$ agarose gel by weighing out $0.75 \mathrm{~g}$ of agarose powder. Add it to a $250-\mathrm{ml}$ bottle containing $50 \mathrm{ml} 1 \mathrm{X}$ TAE buffer. Microwave the bottle with a loosened cap until the gel starts to bubble and become transparent (see Note 10).

\section{Table 2}

\section{Composition of the PCR Reaction}

\begin{tabular}{lcll}
\hline Reagent & $\begin{array}{c}\text { Volume per } \\
\text { reaction }\end{array}$ & $\begin{array}{c}\text { Volume for } \mathrm{N} \\
\text { reactions }\end{array}$ & $\begin{array}{c}\text { Final } \\
\text { concentration }\end{array}$ \\
\hline 10X PCR buffer & $5 \mu \mathrm{l}$ & $5 \times \mathrm{N} \mu \mathrm{l}$ & $1 \mathrm{x}$ \\
$25 \mathrm{mM} \mathrm{MgCl}, 25 \mathrm{mM}$ & $5 \mu \mathrm{l}$ & $5 \times \mathrm{N} \mu \mathrm{l}$ & $2.5 \mathrm{mM}$ \\
$\mathrm{dNTP}, 10 \mathrm{mM}$ & $1 \mu \mathrm{l}$ & $\mathrm{N} \mu \mathrm{l}$ & $0.2 \mathrm{mM}$ \\
Forward primers, $10 \mu \mathrm{M}$ & $1 \mu \mathrm{l}$ & $\mathrm{N} \mu \mathrm{l}$ & $0.2 \mu \mathrm{M}$ \\
Reverse primers, $10 \mu \mathrm{M}$ & $1 \mu \mathrm{l}$ & $\mathrm{N} \mu \mathrm{l}$ & $0.2 \mu \mathrm{M}$ \\
DNA polymerase $(5 \mathrm{U} / \mu \mathrm{l})$ & $0.2 \mu \mathrm{l}$ & $0.2 \times \mathrm{N} \mu \mathrm{l}$ & $1 \mathrm{U} /$ reaction \\
Water & $34.8 \mu \mathrm{l}$ & $34.8 \times \mathrm{N} \mu \mathrm{l}$ & - \\
Total & $48 \mu \mathrm{l}$ & $48 \times \mathrm{N} \mu \mathrm{l}$ & - \\
\hline
\end{tabular}


Table 3

\section{Conditions for the PCR Reaction}

\begin{tabular}{lcc}
\hline Step & Temperature & Time \\
\hline 1. Heat activation & $94^{\circ} \mathrm{C}$ & $10 \mathrm{~min}$ \\
2. Thermal cycling $(45$ cycles) & & \\
Denaturing step & $94^{\circ} \mathrm{C}$ & $30 \mathrm{sec}$ \\
Annealing step & $48^{\circ} \mathrm{C}$ & $30 \mathrm{sec}$ \\
Extension & $72^{\circ} \mathrm{C}$ & $40 \mathrm{sec}$ \\
3. Final extension & $72^{\circ} \mathrm{C}$ & $2 \mathrm{~min}$ \\
4. Soak & $4^{\circ} \mathrm{C}$ & $\infty$ \\
\hline
\end{tabular}

3. Cool the melted agarose to about $60^{\circ} \mathrm{C}$ and pour it into the gel-casting tray. Insert a comb into the tray.

4. Allow the gel to solidify at room temperature.

5. Remove the comb from the tray.

6. Place the tray in the electrophoresis chamber with the wells on the cathode side.

7. Fill the buffer chamber with $1 \mathrm{X}$ TAE buffer at a level that can cover the top of the gel.

8. Mix $0.5 \mu \mathrm{l}$ of the DNA markers with $1 \mu \mathrm{l}$ of $6 \mathrm{X}$ gel loading dye and $4.5 \mu \mathrm{l}$ of water on a parafilm sheet by repeated pipetting.

9. Mix $5 \mu$ l of the PCR products with $1 \mu$ l of $6 \mathrm{X}$ gel loading dye on a parafilm sheet by pipetting up and down several times.

10. Apply the mixture to the corresponding well of the gel.

11. Close the lid of the electrophoresis apparatus and connect the electrical leads, anode to anode (red to red) and cathode to cathode (black to black).

12. Run the gel at $100 \mathrm{~V}$ for $30 \mathrm{~min}$.

13. Turn off the power, remove the cover, and retrieve the gel.

14. Soak the gel in $1 \mathrm{X}$ TAE with $0.5 \mu \mathrm{g} / \mathrm{ml}$ ethidium bromide for $15 \mathrm{~min}$. Wash the gel with water (see Note 3).

15. Place the gel on top of the transilluminator. Switch on the power of the gel documentation machine (see Note 11).

16. Adjust the position of the gel and record the results. The size of the expected product for coronaviruses is $440 \mathrm{bp}$ (Fig. 2).

\subsection{Hemi-Nested PCR for Group 1 Bat Coronaviruses (Optional)}

1. Mix $1 \mu \mathrm{l}$ of the the PCR reaction from Section 3.4 with $9 \mu l$ of water. Use $2 \mu l$ of the diluted samples in the hemi-nested PCR reaction.

2. Repeat the procedure as outlined in Section 3.4, replacing the reverse primer of the PCR reaction by the primer 5'ATCAGATAGAATCATCATAGAGA-3'.

3. Repeat the steps in Section 3.5. The size of the expected PCR product is $435 \mathrm{bp}$. 


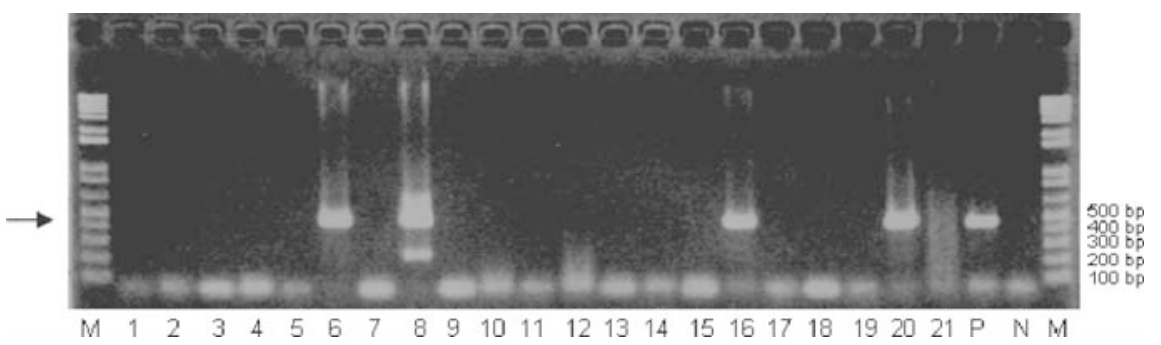

Fig. 2. PCR reaction specific for coronaviruses. The position of expected PCR products (440 nt) is highlighted by the arrow. Positive samples: lanes 5, 8, 16, and 20. Negative samples: lanes 1-5, 7, 9-15, 17—19, and 21. M, DNA markers; P: positive control; $\mathrm{N}$ : water control.

\subsection{PCR Product Purification}

1. When using a new PCR product purification kit, add ethanol (96-100\%) to buffer $\mathrm{PE}$ according the product insert. Vortex the mixture briefly.

2. Mix $200 \mu \mathrm{l}$ of buffer PB to $40 \mu \mathrm{l}$ of PCR products from Section 3.4 or 3.6 in a clean $0.5-\mu l$ microcentrifuge tube.

3. Apply the mixture to a QIAquick column that is inserted in a 2-ml collection tube.

4. Centrifuge the tube at $20,000 \times g(14,000 \mathrm{rpm})$ for $1 \mathrm{~min}$. Discard the flowthrough. Put the column back into the same collection tube.

5. Apply $0.75 \mathrm{ml}$ of buffer PE to the column and repeat step 4 .

6. Transfer the column in a sterile $1.5-\mathrm{ml}$ microcentrifuge tube.

7. Apply $30 \mu \mathrm{l}$ of buffer EB to the membrane of the column. Let it stand for $1 \mathrm{~min}$.

8. Centrifuge the tube at $20,000 \times g(14,000 \mathrm{rpm})$ for $1 \mathrm{~min}$.

9. Discard the column. The PCR products collected in the $1.5-\mathrm{ml}$ microcentrifuge tube are ready for sequencing work (Section 3.9). Alternatively, these samples could be stored at $-20{ }^{\circ} \mathrm{C}$ until use (see Notes 12 and 13).

\subsection{PCR Cloning (Optional)}

1. On the day of the work, spread $40 \mu \mathrm{l}$ of $40 \mathrm{mg} / \mathrm{ml} \mathrm{X-gal} \mathrm{on} \mathrm{selective} \mathrm{agar} \mathrm{plates,}$ each of which contains $50 \mu \mathrm{g} / \mathrm{ml}$ ampicillin. Incubate the plates at $37^{\circ} \mathrm{C}$ until use.

2. Dilute the salt solution provided in the cloning kit by fourfold.

3. Thaw a vial of electrocompetent $E$. coli on ice.

4. Mix $4 \mu$ l of purified PCR products from Section 3.7 with $2 \mu l$ of fourfold diluted salt solution in a sterile $0.5-\mathrm{ml}$ microcentrifuge tube by pipetting up and down several times.

5. Mix $1 \mu \mathrm{l}$ TOPO vector into the reaction with a gentle pipetting.

6. Incubate for $5 \mathrm{~min}$ at room temperature. 
7. Transfer $2 \mu \mathrm{l}$ of reaction product into the thawed competent cells. Mix the contents by gently tapping the tube.

8. Carefully transfer the competent cells to an ice-chilled cuvette. Try to avoid forming bubbles in the cuvette.

9. Insert the cuvette into the electroporation chamber. Transfect the cells under these parameters: $2.5 \mathrm{kV}, 200 \Omega$, and $25 \mu \mathrm{F}$.

10. Add $250 \mu \mathrm{l}$ SOC medium provided from the cloning kit to the transfected cells.

11. Tranfect the solution into a $1.5-\mathrm{ml}$ microcentrifuge tube and incubate it at $37^{\circ} \mathrm{C}$ with shaking.

12. Spread $100 \mu \mathrm{l}$ of the incubated solution on a prewarmed selective plate. Incubate the plate at $37^{\circ} \mathrm{C}$ overnight in an inverted position.

13. Select 5 to 10 white colonies for PCR screening. Use sterile pipette tips to touch the selected colonies. Preserve the selected colonies by touching the pipette tips on a patch LB plate. Label the colonies accordingly. Incubate the plate at $37^{\circ} \mathrm{C}$ in an inverted position. Keep the plate at $4{ }^{\circ} \mathrm{C}$ after an overnight incubation.

14. Transfer the rest of the contents attached to the pipette tips into $0.5-\mu 1$ microcentrifuge tubes containing $20 \mu \mathrm{l}$ of $10 \mathrm{mM}$ Tris-HCl, pH 7.4. Label the tubes accordingly. Vortex the tubes briefly.

15. Heat the tubes at $95^{\circ} \mathrm{C}$ for $10 \mathrm{~min}$. Then chill them on ice and centrifuge briefly.

16. Depending on the source of the PCR products, repeat the PCR protocol as described in Section 3.4 or 3.6. Use $2 \mu$ l of heat-treated supernatants as the DNA template in these reactions.

17. Analyze the size of the inserts of these clones according to the procedures described in Section 3.5. Only those with the expected product sizes (i.e., $440 \mathrm{bp}$ for protocol 3.4; $435 \mathrm{bp}$ for protocol 3.6) will be selected for PCR sequencing. Purify the positive samples as described in Section 3.7 before DNA sequencing.

18. Pick the desired clones off the patch plate and put them into $1 \mathrm{ml}$ of LB containing $50 \mu \mathrm{g} / \mathrm{ml}$ of ampicillin. Grow the culture for $16-20 \mathrm{~h}$. Mix $0.85 \mathrm{ml}$ of the culture with $0.15 \mathrm{ml}$ of sterile glycerol. Keep the transformed cells at $-80^{\circ} \mathrm{C}$ for long-term storage.

\subsection{PCR Sequencing}

1. Measure the concentration of the purified amplicons using a spectrophotometer. The concentration of DNA in $\mu \mathrm{g} / \mu \mathrm{l}=\left(\mathrm{OD}_{260} \times\right.$ volume of diluted sample $) /$ $(20 \times$ volume of sample used for dilution).

2. Prepare the sequencing reaction in 96-well plate format. Mix 5-10 ng of the purified products with $1 \mu \mathrm{l}$ of diluted forward or reverse PCR primers $(3.2 \mu \mathrm{M})$ used in Section 3.4 or 3.6. Adjust the final volume of the reaction to $12 \mu \mathrm{l}$ with sterile water. Add $8 \mu$ l of Terminator Ready Reaction mix. Centrifuge the tube briefly. Keep the tube on ice.

3. Run the sequencing reactions under the conditions described in Table 4. 


\section{Table 4}

\section{Conditions for Sequencing Reactions}

\begin{tabular}{lcc}
\hline Step & Temperature & Time \\
\hline 1. Heat denaturing & $94^{\circ} \mathrm{C}$ & $1 \mathrm{~min}$ \\
2. Thermal cycling (25 cycles) & & \\
Denaturing step & $94^{\circ} \mathrm{C}$ & $30 \mathrm{sec}$ \\
Annealing step & $50^{\circ} \mathrm{C}$ & $15 \mathrm{sec}$ \\
Extension & $60^{\circ} \mathrm{C}$ & $4 \mathrm{~min}$ \\
3. Soak & $4^{\circ} \mathrm{C}$ & $\infty$ \\
\hline
\end{tabular}

4. Store the reaction products at $4{ }^{\circ} \mathrm{C}$ until ready for purification.

5. Briefly vortex the dye removal columns to resuspend the gel.

6. Snap off the tip, remove the cap, and insert it into a clean microcentrifuge tube from the purification kit.

7. Centrifuge the tube at $1000 \times g(3300 \mathrm{rpm})$ for $2 \mathrm{~min}$.

8. Discard the flow-through.

9. Apply $200 \mu \mathrm{l}$ of water to each column. Centrifuge the tube at $1000 \times g(3300 \mathrm{rpm})$ for $2 \mathrm{~min}$. Transfer the columns into clean microcentrifuge tubes.

10. Carefully apply the sequencing products $(\sim 20 \mu l)$ to the gel matrix in the columns.

11. Centrifuge the tube at $1000 \times g(3300 \mathrm{rpm})$ for $2 \mathrm{~min}$. Discard the columns and store the tubes containing the purified sequencing products at $-20^{\circ} \mathrm{C}$.

12. Transfer $10 \mu \mathrm{l}$ of the purified products to a 96-well sample loading plate. Seal the plate with a heat seal and load it into the DNA analyzer for analysis.

13. Run the DNA analyzer.

14. Analyze the deduced sequences (see Notes 14 and 15).

\section{Notes}

1. Viral transport medium contains a high concentration of antibiotic to inhibit bacterial growth.

2. Buffer AVL containing carried RNA might form white precipitates when it is stored at $4{ }^{\circ} \mathrm{C}$. The precipitates can be dissolved in the buffer by heating the bottle in a water bath. Cool the buffer to room temperature before use.

3. Ethidium bromide is a known mutagen and may be carcinogenic. Handle solutions of ethidium bromide with gloves.

4. For reasons of safety, staffs who are required to handle animals should have the appropriate inoculations (e.g., rabies vaccine for handling bats). Appropriate protective equipment should be worn when handling animals.

5. Bats are protected species in Hong Kong, and a permit from the relevant governmental office is required to perform the work. 
6. For some small bat species, the finest swabs used in our studies are still too big to fit into the anal opening. In this situation, we use fecal instead of anal samples. To minimize possible contamination, these bats are kept individually in clean cotton bags for a few minutes. Fecal pellets collected in the cotton bags are sampled for further analysis.

7. In our study, we also tried to isolate viruses from our samples. As some viruses might be sensitive to repeat freeze and thaw cycles, we normally aliquot the original samples into two separate tubes. One tube is kept at $-80^{\circ} \mathrm{C}$ for long-term storage and the other is kept at $4^{\circ} \mathrm{C}$ until it is ready for RNA extraction and virus isolation.

8. Contents in fecal samples and calcium alginate in swabs are known to inhibit RT-PCR assays. One should validate the protocols and test the reagents with specimens spiked with positive samples in advance. RNA purified from our recommended RNA extraction kit work well for us.

9. General procedures to prevent PCR cross-contamination should be strictly followed. Aerosol-resistant filtered pipette tips could minimize possible carryover of amplicons. Separate pipettes and areas are used for sample processing, PCR, and post-PCR analysis. It is essential to include multiple positive and negative controls in the PCR reactions when a large number of samples are tested at the same time.

10. Agarose solutions can be superheated in a microwave oven. Do not handle the bottle immediately after microwaving. Always wear heat-resistant gloves when handling melted agarose.

11. UV light can cause severe skin and eye damage. Wear safety glasses and close the photography hood before turning on the UV transilluminator.

12. Purified PCR products from Section 3.7 can be directly subjected to DNA sequencing. As quiescent species were found in our studied bat samples, we observed several single nucleotide polymorphisms in the products. To obtain more accurate sequencing data for our phylogenetic analysis, PCR products from these reactions were cloned into vectors (Section 3.8) and several clones from the same PCR reaction were randomly selected for further analysis.

13. On some occasions, nonspecific PCR products might be observed (lane 8, Fig. 1) and the desired PCR products have to be recovered by direct excisions from the agarose gel. As UV can damage DNA, it is important to use low-energy UV light to visualize and locate the desired product in this scenario. Try to excise the product as quickly as possible. We normally purify the excised products using a QIAquick gel extraction kit (Qiagen). The purified products can be subjected to cloning or sequencing as noted.

14. The products should be sequenced in both directions.

15. Deduced sequences are normally analyzed on both DNA and amino acid levels. Common sequence databases, such as Genbank (http://www.ncbi.nlm.nih.gov/ Genbank/) can be used for the analysis. Common analytic freeware such as BioEdit (http://www.mbio.ncsu.edu/BioEdit/bioedit.html) and MEGA (http:// www.megasoftware.net/) are commonly used analytical programs and are available on the Internet. 


\section{Acknowledgments}

Funding for this research was provided by a Public Health Research Grant from the National Institute of Allergy and Infectious Diseases, USA, the Research Grant Council of Hong Kong (HKU 7343/04 M to LLMP), and the European Research Project SARS-DTV (Contract No: SP22-CT-2004).

\section{References}

1. Gorbalenya, A. E., Enjuanes, L., Ziebuhr, J., and Snijder, E. J. (2006) Nidovirales: evolving the largest RNA virus genome. Virus. Res. 117, 17-37.

2. Saif, L. J. (2004) Animal coronavirus vaccines: lessons for SARS. Dev. Biol. (Basel) 119, 129-140.

3. Weiss, S. R., and Navas-Martin, S. (2005) Coronavirus pathogenesis and the emerging pathogen severe acute respiratory syndrome coronavirus. Microbiol. Mol. Biol. Rev. 69, 635-664.

4. Fouchier, R. A., Hartwig, N. G., Bestebroer, T. M., Niemeyer, B., de Jong, J. C., Simon, J. H., and Osterhaus, A. D. (2004) A previously undescribed coronavirus associated with respiratory disease in humans. Proc. Natl. Acad. Sci. USA 101, 6212-6216.

5. van der Hoek, L., Pyrc, K., Jebbink, M. F., Vermeulen-Oost, W., Berkhout, R. J., Wolthers, K. C., Wertheim-van Dillen, P. M., Kaandorp, J., Spaargaren, J., and Berkhout, B. (2004) Identification of a new human coronavirus. Nature Med. 10, 368-373.

6. Woo, P. C., Lau, S. K., Chu, C. M., Chan, K. H., Tsoi, H. W., Huang, Y., Wong, B. H., Poon, R. W., Cai, J. J., Luk, W. K., Poon, L. L., Wong, S. S., Guan, Y., Peiris, J. S., and Yuen, K. Y. (2005) Characterization and complete genome sequence of a novel coronavirus, coronavirus HKU1, from patients with pneumonia. J. Virol. 79, 884-895.

7. Guan, Y., Zheng, B. J., He, Y. Q., Liu, X. L., Zhuang, Z. X., Cheung, C. L., Luo, S. W., Li, P. H., Zhang, L. J., Guan, Y. J., Butt, K. M., Wong, K. L., Chan, K. W., Lim, W., Shortridge, K. F., Yuen, K. Y., Peiris, J. S., and Poon, L. L. (2003) Isolation and characterization of viruses related to the SARS coronavirus from animals in southern China. Science 302, 276-278.

8. Chu, D. K., Poon, L. L., Chan, K. H., Chen, H., Guan, Y., Yuen, K. Y., and Peiris, J. S. (2006) Coronaviruses in bent-winged bats (Miniopterus spp.). J. Gen. Virol. 87, 2461-2466.

9. East, M. L., Moestl, K., Benetka, V., Pitra, C., Honer, O. P., Wachter, B., and Hofer, H. (2004) Coronavirus infection of spotted hyenas in the Serengeti ecosystem. Vet Microbiol 102, 1-9.

10. Jonassen, C. M., Kofstad, T., Larsen, I. L., Lovland, A., Handeland, K., Follestad, A., and Lillehaug, A. (2005) Molecular identification and characterization of novel coronaviruses infecting graylag geese (Anser anser), feral pigeons (Columbia livia) and mallards (Anas platyrhynchos). J. Gen. Virol. 86, 1597-1607. 
11. Lau, S. K., Woo, P. C., Li, K. S., Huang, Y., Tsoi, H. W., Wong, B. H., Wong, S. S., Leung, S. Y., Chan, K. H., and Yuen, K. Y. (2005) Severe acute respiratory syndrome coronavirus-like virus in Chinese horseshoe bats. Proc. Natl. Acad. Sci. USA 102, 14040-14045.

12. Li, W., Shi, Z., Yu, M., Ren, W., Smith, C., Epstein, J. H., Wang, H., Crameri, G., Hu, Z., Zhang, H., Zhang, J., McEachern, J., Field, H., Daszak, P., Eaton, B. T., Zhang, S., and Wang, L. F. (2005) Bats are natural reservoirs of SARS-like coronaviruses. Science 310, 676-679.

13. Pearks Wilkerson, A. J., Teeling, E. C., Troyer, J. L., Bar-Gal, G. K., Roelke, M., Marker, L., Pecon-Slattery, J., and O'Brien, S. J. (2004) Coronavirus outbreak in cheetahs: lessons for SARS. Curr. Biol. 14, R227- R228.

14. Poon, L. L., Chu, D. K., Chan, K. H., Wong, O. K., Ellis, T. M., Leung, Y. H., Lau, S. K., Woo, P. C., Suen, K. Y., Yuen, K. Y., Guan, Y., and Peiris, J. S. (2005) Identification of a novel coronavirus in bats. J. Virol. 79, 2001-2009.

15. Tang, X. C., Zhang, J. X., Zhang, S. Y., Wang, P., Fan, X. H., Li, L. F., Li, G., Dong, B. Q., Liu, W., Cheung, C. L., Xu, K. M., Song, W. J., Vijaykrishna, D., Poon, L. L., Peiris, J. S., Smith, G. J., Chen, H., and Guan, Y. (2006) Prevalence and genetic diversity of coronaviruses in bats from China. J. Virol. 80, 7481-7490.

16. Wise, A. G., Kiupel, M., and Maes, R. K. (2006) Molecular characterization of a novel coronavirus associated with epizootic catarrhal enteritis (ECE) in ferrets. Virology 349, 164-174.

17. Woo, P. C., Lau, S. K., Li, K. S., Poon, R. W., Wong, B. H., Tsoi, H. W., Yip, B. C., Huang, Y., Chan, K. H., and Yuen, K. Y. (2006) Molecular diversity of coronaviruses in bats. Virology 351, 180-187. 